\title{
Warm Climate Production Guidelines for Angelonia ${ }^{1}$
}

\section{Richard Schoelhorn and Erin Alvarez ${ }^{2}$}

\section{Introduction}

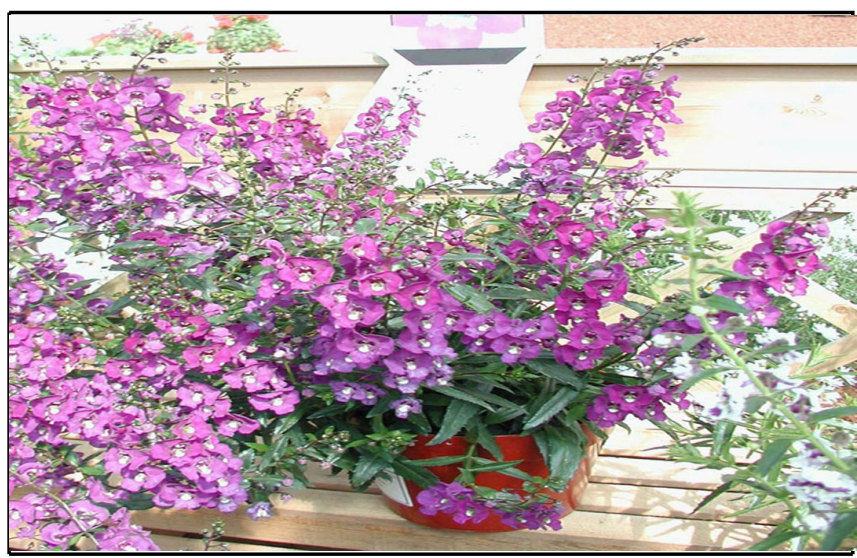

Figure 1. Angelonia angustifolia.

Common Name: Angelonia

Scientific Name: Angelonia angustifolia

Family: Scrophulariaceae

Angelonia is a popular warm-season annual that has a renewed interest for growers and consumers due to the development of several new cultivars. Depending on the chosen cultivar, it reaches from from 1 to 3 feet high, and up to 3 feet wide. Its leaves may be glossy green, or gray-green with hairs, and are $1 / 2$ inch wide by 1-2 inches long with a slightly sticky texture. When bruised, leaves release a scent reminiscent of grape soda. Angelonia inflorescences are comprised of a dozen or more 1-inch blooms that come in several colors. It is most often grown as an annual bedding plant, but may survive winters in zones 9 and 10. Angelonia is excellent for use in the landscape and in large containers, and is becoming more popular for cut flower use. Known as the summer snapdragon, this plant does best in warm climates, is drought tolerant, and really shines when snapdragons and other spring annuals begin to wither. Older varieties vary in performance. Most are treated as annuals, but in all Florida zones they can be perennial if the winter is mild.

\section{Production}

\section{Media}

- Use a well-drained, light, soilless medium with a $\mathrm{pH}$ of 5.5-6.2.

\section{Light Levels}

- 5,000 foot candles (f.c.) minimum.

- Keep light levels as high as possible within recommended temperatures.

1. This document is ENH 877, one of a series of the Environmental Horticulture Department, Florida Cooperative Extension Service, Institute of Food and Agricultural Sciences, University of Florida. Original publication date October 15, 2002. Visit the EDIS Web Site at http://edis.ifas.ufl.edu.

2. Richard Schoellhorn, Associate Professor; Erin Alvarez, Student Assistant, Environmental Horticulture Department, Institute of Food and Agricultural Science, University of Florida, Gainesville, Fl 32611.

The Institute of Food and Agricultural Sciences (IFAS) is an Equal Employment Opportunity - Affirmative Action Employer authorized to provide research, educational information and other services only to individuals and institutions that function without regard to race, creed, color, religion, age, disability, sex, sexual orientation, marital status, national origin, political opinions or affiliations. For information on obtaining other extension publications, contact your county Cooperative Extension Service office. Florida Cooperative Extension Service / Institute of Food and Agricultural Sciences / University of Florida / Larry R. Arrington, Interim Dean 


\section{Production Temperatures}

- Day: $75-82^{\circ} \mathrm{F}$.

- Night: $62-65^{\circ} \mathrm{F}$.

- Temperatures below $60^{\circ} \mathrm{F}$ will slow growth and delay blooming. Cooler temperatures can be used if slower growth is desired.

\section{Watering}

- Media should be moderately dry between each watering.

- Leaf tip burn may result from excessive dryness; don't allow plants to wilt.

\section{Fertilization}

- Angelonia are fairly heavy feeders initially.

- Maintain continuous 150-200 ppm N liquid feed, or incorporate slow-release granular at medium rates.

- When buds first appear, reduce fertilization by half.

\section{Propagation}

- Non-patented cultivars can be propagated vegetatively by tip cuttings, which will root easily.

- Apply growth hormone to cuttings and place in rooting medium with bottom heat.

- Rooting should occur in 7-10 days.

- May also be propagated by seed, but is primarily produced vegetatively.

\section{Scheduling}

- Crop timing will vary by climate and growing environment.

- Rooted cuttings produce the most uniform finished crop.

- Rooted Cuttings:
- 6-inch pot: 1-2 plants per pot, 6-10 weeks.

-1-gallon pot: 2 plants per pot, 6-10 weeks.

- Unrooted Cuttings:

- 6-inch pot: 1-2 plants per pot, 8-12 weeks.

-1-gallon pot: 2 plants per pot, 8-12 weeks.

\section{Pinching}

- First pinch to 3-5 nodes 10-14 days after transplanting.

- An optional second pinch to 3 nodes for plants in containers larger than 4 inches.

- Plants may also be sheared to induce re-bloom.

\section{Photoperiod}

- Day neutral.

\section{Plant Growth Regulators}

- The need for and effects of plant growth regulators vary greatly depending on a number of factors. It is always recommended that growers test plant growth regulators before use. Always follow label instructions.

-4-16 ppm Paclobutrazol drench.

- To 3 applications of a Cycocel (1,500 ppm) and B-Nine (3,000 ppm) mix starting 10 to 14 days after first pinch.

- Florel may cause leaf tips to burn.

\section{Common Problems}

- Wet media for prolonged periods will promote bacteria and fungal growth and can lead to plant collapse; allow media to dry between waterings to prevent this.

- Excessive vegetative growth can be the result of high ammonia levels, over-fertilizing and over-watering in low light, or low temperatures. 
- Low fertilization and low light can also contribute to poor branching and stretching of plants.

\section{Landscape Culture}

- Plant in full sun in a moderate to dry location.

- Space plants 12 to 16 inches apart in garden beds.

- Apply a balanced, slow-release 18-6-12 fertilizer.

- Shear plants back 50\% mid-season to improve plant health and for a heavy rebloom 2-3 weeks later.

- Angelonia has few pests other than Angelonia looper, which affects plants as a stem- and tip-boring caterpillar. This can be treated with Sevin or B. thurengiensis.

\section{Recommended Cultivars}

\section{Patented}

- Ball AngelMist series is virus-free, large, and vigorous. It comes in six different colors, ranging from deep plum to lavender.

- Proven Winners has the Angelface Series, with the largest flowers and a more upright growth habit.

- The Flowerfields series Cartias has smaller flowers on well-branched plants. Red-violet tones are available in this series.

\section{Non-Patented}

- 'Alba' has white flowers.

- 'Blue Pacifica' blooms in two-toned white and blue flowers.

- 'Pandiana' has pale pink blooms with silvery foliage. 